\title{
75\% of Global Blindness Cases in Southeast Asia
}

\author{
Tariq Masood* \\ Tree Tops The Eye Centre, Pakistan
}

Submission: March 12, 2017; Published: May 04, 2017

*Corresponding author: Tariq Masood, General Manager, Tree Tops The Eye Centre, 3F/1 Wapda Town, Lahore, Pakistan, Tel: +923246161786; Email: t.masood@live.com

\section{Mini Review}

Considerable efforts in many developing countries, through blindness prevention programs, the global number of blind and visually disabled seems to be growing, mainly as an effect of population increase and aging. The population of south East Asia is about 593 million, since the main cause of blindness is cataract and only in this region 283 million people are effected by cataract, 73 million by glaucoma, 52 million by age related macular degeneration, 30 million by corneal opacity and 28 million by diabetic retinopathy. More than $75 \%$ of blindness is preventable since the most important factor to understand is that around same number of the blind people could see again if they had eye care facilities in their related areas or regions.

Cataract, childhood blindness, refractive error and low vision, glaucoma, and diabetic retinopathy are the leading causes of blindness. On average throughout south east Asia there is one ophthalmologist for around 200,000 people, and one mid level eye care personnel for around half a million of the population. Most of the eye care personnel are located in large cities and populated towns; on the contrary, around $75 \%$ of the population lives in rural areas, thus making access to eye health services is a major challenge.

Road blocks like surgical cost, lack of family support, and failure to understand the need for surgery and other social, infrastructural, and geographic factors, such as availability of ophthalmologists in rural regions particularly and difficulties in accessing eye-care centers with patients having to travel too far. Quality of cataract surgery is also remains a concern, with poor outcomes reaching $40 \%$ in some places. In fact, many ophthalmologists do not perform surgery or may be inadequately trained. Cataract, therefore, continues to be a challenge to handle with the need to plan a comprehensive strategy addressing issues related to availability, affordability, accessibility, and acceptability of eye-care services, and improving outcome of cataract surgery in low- and middle-income countries.
Globally, women as compared with men had a larger percentage of blindness caused by cataract. Worldwide, $35.5 \%$ of blindness among women was caused by cataract versus $30.1 \%$ of blindness among men. It is estimated that blindness and severe impairment from cataract could be reduced by approximately $11 \%$ in the low- and middle-income countries if women were to receive cataract surgery at the same rate. Additional focus is needed to bring cataract surgical services to women mainly in low- and middle-income south east Asian countries.

It has been estimated very carefully that half of all the world's blindness is preventable or treatable. Cataract, for example, is well on its way to being eliminated as a major cause of blind $\neg$ ness in developed nations. Improvements in cataract surgery have resulted in an operation that is $95 \%$ successful and is considered one of the safest and most efficacious of all major operations.

Blindness is significantly affects not only the immediate family but by enlarge the whole community. The blindness restricts mobility and requires some assistance for everyday work and task. Consequently, blindness affects the community on a practical level, as children cannot attend school when they become caretakers for blind adults. Thus, countless children are denied the opportunity to receive a basic education, when a sighted adult becomes the caretaker for a blind individual, he or she must stop working partially or complete. This leads to longterm economic and educational repercussions. Consequently the family earning become reduced which put the family in further poverty, frustration, depression and health issues.

To reduce or avoid the blindness in south east Asia an effective ophthalmic services, like cataract surgery, the screening for, and treatment of, diabetic retinopathy. The eye care centres having facilities of high quality, efficient and low-cost cataract surgery is the need of the time. The WHO and world health organizations should have more focus on developing countries or region like 
south east Asia. The effective eye care services require more coordinated and integrated planning, modules and efforts of services from the primary, secondary and tertiary levels. The need of outreach eye care services for rural areas under able supervision could bring tremendous results.

The eye care organizations are putting substantial efforts to build more hospitals and equip them, but right dedicated volunteers, ophthalmologists team and processes need to place according to the need and demand of area or region to ensure targeted outcome..More over significantly enhancement in resource base, infrastructure, equipment, eye specialists and other ophthalmic workers are needed to emplace along with equal emphasis to build and emplace task management teams to build the right processes and the organizational capability for maximal cost-effective resource utilization. Patient access, affordability and availability of surgical consumables and pharmaceuticals are all part of task management teams.

Focused, clear and transparent strategies are required to reduce global burden of blindness which require a global vision and local implementation. These strategies share a public health focus and community awareness blindness and eye care.

Your next submission with Juniper Publishers will reach you the below assets

- Quality Editorial service

- Swift Peer Review

- Reprints availability

- E-prints Service

- Manuscript Podcast for convenient understanding

- Global attainment for your research

- Manuscript accessibility in different formats

(Pdf, E-pub, Full Text, Audio)

- Unceasing customer service

Track the below URL for one-step submission .https://juniperpublishers.com/online-submission.php 